\title{
IMPAIRED TISSUE INTEGRITY, RELATED FACTORS AND DEFINING CHARACTERISTICS IN PERSONS WITH VASCULAR ULCERS ${ }^{1}$
}

\author{
Suelen Gomes Malaquias², Maria Márcia Bachion³, Marlene Andrade Martins", Cynthia Assis de Barros \\ Nunes ${ }^{5}$, Gilson de Vasconcelos Torres ${ }^{6}$, Lilian Varanda Pereira ${ }^{7}$
}

\footnotetext{
${ }^{1}$ Part of the master's dissertation "Impaired integrity of the skin in the perilesional area and impaired tissue integrity related to altered circulation in persons with vascular ulcers", defended in the Postgraduate Program in Nursing of the Faculty of Nursing (FEN), Federal University of Goiás (UFG), in 2010.

${ }^{2}$ Doctoral student on the Postgraduate Program in Health Sciences, UFG. Assistant Professor on the Undergraduate Nursing Course, UFG. Goiás, Brazil. Email: sgmalaquias@gmail.com

${ }^{3}$ Ph.D. in Nursing. Full professor, FEN-UFG. Goiás, Brazil. Researcher of the National Council for Scientific and Technological Development (CNPq). Email: mbachion@gmail.com

${ }^{4}$ Ph.D. in Health Sciences. Adjunct professor on the Undergraduate Nursing Course, UFG. Goiás, Brazil. Email: marlenianapower@hotmail.com

${ }^{5}$ M.Sc. in Nursing. RN of the Goiânia Municipal Health Department. Goiás, Brazil. Email: cynthiaassisdebarros@yahoo.com.br

${ }^{6}$ Ph.D. in Nursing. Full professor of the Department of Nursing of the Federal University of Rio Grande do Norte. Rio Grande do Norte, Brazil. CNPq Researcher. Email: gilsonvtorres@hotmail.com

7 Ph.D. in Nursing. Adjunct professor FEN/UFG. Goiás, Brazil. Email: lilianvaranda7@gmail.com
}

\begin{abstract}
This transversal study aimed to analyze factors related to, and defining characteristics of, Impaired Tissue Integrity in persons with vascular ulcers, and compare the mean of these factors between the groups presenting different degrees in the severity of tissue compromise. The study was undertaken in February-August 2009, in the municipal health network of Goiânia in the state of Goiás, using interviews, clinical examinations and photographic records of the wounds. For analysis, simple and percentage frequencies and the Student t-test $(\mathrm{p}<0.05)$ were used. Five related factors were identified in more than half of the 42 participants: impaired circulation, knowledge deficit, chemical irritants, fluid excess and nutritional factors. Three defining characteristics were identified in all of the participants. There was no difference in the mean of related factors between groups. Impaired Tissue Integrity in persons with vascular ulcers was a phenomenon which demands professional attention extending beyond circulatory impairment. The mean of factors did not indicate greater or lesser severity of the compromising of the tissue integrity.
\end{abstract}

KEYWORDS: Nursing diagnosis. Leg ulcer. Varicose ulcer. Primary health care. Nursing.

\section{INTEGRIDADE TISSULAR PREJUDICADA, FATORES RELACIONADOS E CARACTERÍSTICAS DEFINIDORAS EM PESSOAS COM ÚLCERAS VASCULARES}

RESUMO: Objetivou-se analisar fatores relacionados e características definidoras de Integridade Tissular Prejudicada em pessoas com úlceras vasculares e comparar a média desses fatores entre grupos que apresentavam diferentes graus na gravidade do comprometimento dos tecidos. Pesquisa transversal, realizada de fevereiro a agosto de 2009, na rede municipal de saúde de Goiânia-GO utilizando-se entrevista, exame clínico e registro fotográfico da lesão. Para análise, utilizou-se freqüência simples e percentual e teste $t$ de Student $(p<0,05)$. Identificaram-se cinco fatores relacionados em mais da metade dos 42 participantes: circulação prejudicada, déficit de conhecimento, irritantes químicos, excesso de líquidos e fatores nutricionais. Três características definidoras foram identificadas em todos os participantes. Não houve diferença na média de fatores relacionados entre grupos. Integridade Tissular Prejudicada em pessoas com úlceras vasculares configurou-se fenômeno que demanda atenção profissional para além do comprometimento da circulação. A média de fatores não indicou maior ou menor gravidade do comprometimento da integridade tissular.

PALAVRAS CHAVE: Diagnóstico de enfermagem. Úlcera da perna. Úlcera varicosa. Atenção primária à saúde. Enfermagem. 


\title{
DETERIORO DE LA INTEGRIDAD CUTÁNEA, FACTORES RELACIONADOS Y CARACTERÍSTICAS DETERMINANTES EN PERSONAS CON ÚLCERAS VASCULARES
}

\begin{abstract}
RESUMEN: Se objetivó analizar factores relacionados, características determinantes en el deterioro de la integridad tisular en personas con úlceras vasculares y comparar los promedios de los factores entre grupos que presentaban diferentes grados de comprometimiento tisular. Pesquisa transversal, realizada de febrero - agosto/ 2009, en la red municipal de salud de Goiânia, utilizándose entrevista, examen clínico y registro fotográfico de la lesión. Para el análisis se utilizó frecuencia simple y porcentual y prueba t de Student $(p<0,05)$. Se identificaron cinco factores en la mayoría de los 42 participantes: circulación perjudicada, déficit de conocimiento, irritantes químicos, exceso de líquidos y factores nutricionales. Tres características fueron identificadas en los participantes. No hubo diferencia en promedio de factores entre grupos. La integridad tisular deteriorada en personas con úlceras vasculares se configuró como un fenómeno que demanda atención profesional más allá del comprometimiento circulatorio. El promedio de FR no indicó mayor o menor gravedad del comprometimiento de la integridad tisular.
\end{abstract}

PALABRAS CLAVE: Diagnóstico de enfermería. Úlcera de la pierna. Úlcera varicosa. Atención primaria de salud. Enfermería.

\section{INTRODUCTION}

The need to describe the phenomena observed in clinical and nursing practice is unquestionable, if one is to contribute to the scientific basis of knowledge in this area. In assisting persons with vascular ulcers, one phenomenon of interest to the profession is the nursing diagnosis of Impaired Tissue Integrity (ITI). This diagnosis was included in the NANDA International taxonomy II, in 1978, was revised in 1998, and has not been modified since then. It is defined as "damage to the mucous membrane, corneal, integumentary, or subcutaneous tissue" 1:496

Studies led by nurses have focused on the identification of the prevalence of the ulcers, ${ }^{2}$ the approach of the person with an ulcer for treatment of the wound, ${ }^{3-7}$ the socio-demographic and clinical characteristics of the population affected, ${ }^{7-9}$ the quality of life of people with venous ulcers, ${ }^{10}$ the psychosocial impact of the ulcers on the person with these lesions, ${ }^{11-12}$ the care practices in primary healthcare, ${ }^{5,7-8}$ predictive factors for healing, ${ }^{13}$ and adherence to the treatment, ${ }^{14}$ differentiation between the ulcer with a venous or arterial etiology, ${ }^{15}$ microbiological analysis of the ulcers ${ }^{16}$ and evaluation of the pain before, during and after the application of dressings. ${ }^{17}$ In a review of the literature, only two studies were found which referred to the identification of nursing diagnoses in persons with vascular ulcers, both undertaken in the hospital context. ${ }^{14,18}$ In these studies, the authors attributed to the participants the nursing diagnosis of Impaired Skin Integrity (ISI).

Considering that the vascular ulcers can compromise the epidermis and dermis or deeper tissues; ${ }^{15,19}$ that, by definition, ulceration is an elementary lesion by solution of continuity, affecting the entire dermis and subcutaneous tissue, being able to affect muscles or bones, without a tendency to repair; ${ }^{20}$ and that the diagnosis of ITI is understood as the condition in which there is damage to the layers of the skin, which can affect the deepest tissues, ${ }^{1}$ it is supposed that the most appropriate diagnostic attribution, in cases of vascular ulcer, would be that of impaired tissue integrity. It is noteworthy that, in the case of superficial ulcers, both the diagnoses of impaired skin integrity and impaired tissue integrity apply, but that in the case of the deeper ulcers, the human response observed is impaired tissue integrity.

Therefore, the hypothesis is defended that people with vascular ulcers present impaired tissue integrity, related to impaired circulation, and, in the individualized clinical approach, other related factors can be found, among those stipulated for the nursing diagnosis in question, which need to be known and understood.

In this context, the hypothesis that the occurrence of more related concomitant factors could be found in the cases of greater severity of compromise of the tissues, in persons with vascular ulcers, as these could negatively influence the tissues' health and the healing process synergetically, is recognized. In the literature, clinical parameters of compromise of tissue vitality are based in the indicators of the severity of the alteration of the venous circulation, which include, among others, a history of the recurrence of the wound, a higher number of wounds, and longer duration of the wound. ${ }^{13,21}$ The indicators mentioned were not studied in relation to the degree of change in the arterial circulation.

For the diagnosis of ITI there are two defining characteristics stipulated in the NANDA-I taxonomy ${ }^{1}$ which seem difficult to distinguish: injured tissue and destroyed tissue, requiring definition, 
and which do not adequately describe the evidence for this human response, demanding the proposal of other defining characteristics.

In the light of the above, the present study was undertaken with the objectives of analyzing the related factors (RFs) and defining characteristics (DCs) of ITI in persons with vascular ulcers, and to compare the mean of RF between groups with the clinical conditions denoting differing degrees of severity of tissue compromise.

This study's results will contribute to the refining of nursing scientific knowledge, and, more specifically, to the better understanding of the diagnosis of ITI in persons with vascular ulcers, providing a broader, stronger, more consistent basis for clinical practice and for teaching.

\section{METHODOLOGY}

This clinical, transversal study, with a quantitative approach, was undertaken between February and August 2009 in the dressings rooms of 13 outpatient health centers in the municipality of Goiânia in the State of Goias (GO), Brazil, representing the services with the highest flow of users with this type of health problem in the municipality. At the time of the undertaking of the study, 67 persons were identified with vascular ulcers being treated in these centers. This contingent was considered the population for this study and the researchers sought to approach all of them, so as to ascertain their eligibility to participate in the study. The following criteria were observed for inclusion: to be aged 18 years old or over, and to be able to manifest one's decision regarding voluntary participation in the study. The following losses occurred: 23 service users did not complete all the items for evaluation in the data collection instrument (22 stopped having dressings applied in the units studied, and one died), one declined to participate in the study and one service user was unable to express his consent to participate in the study. Hence, 42 persons were included, with 63 vascular ulcers in the lower extremities.

Data collection was undertaken through the administration of a protocol developed by the team of authors, containing interviews, clinical examinations and photographic records of the wounds. The interview investigated identification data and socio-economic and socio-demographic aspects. Through the clinical examination, data on the ulcers and the clinical indicators relating to the RFs and DCs for ITI were obtained, in ac- cordance with the NANDA-I taxonomy II, version 2007-2009, which remained unchanged in the subsequent versions until that of 2012-2014, ${ }^{1}$ and with the specialized literature. ${ }^{19-25}$ For each RF and DC found in the NANDA-I, ${ }^{1}$ a definition was elaborated, taking into account the context of the vascular ulcers; and, based in the literature, the respective indicators to be evaluated in the protocol were established. Additions were made to the RFs and DCs of the diagnosis studied, as a result of the understanding that some phenomena identified among the participants were not covered for this diagnosis of the NANDA-I taxonomy, ${ }^{1}$ which were written in italics for appropriate differentiation and which will be described below. These changes aimed to contribute such that the diagnosis studied might better represent the phenomena observed in clinical practice.

It stands out that, in the above-mentioned taxonomy, ${ }^{1}$ the related factors are considered as those which precede, contribute to, promote or are associated with the diagnosis, rather than simply the factors which represent direct causes for the diagnosis. The defining characteristics are evidence for the diagnoses.

The following related factors and indicators were evaluated:

- Mechanical factors: traumas of any etiology, such as blows or scratches, which culminate in impairment of the local tissue integrity. Indicators evaluated: history of fractures, blows, excoriation, scratches, cuts/laceration or insect bite, prior to the appearance of the lesion. ${ }^{19-20,22}$

- Extremes of temperature: extremely cold or hot temperatures, capable of provoking burns in the body tissues. Indicators evaluated: history of the application of heat and/or cold in the lower extremities or exposure to, or contact with, very hot or cold temperatures, ${ }^{20}$ with consequent burn(s), prior to the appearance of the ulcer.

- Radiation: previous exposure to solar radiation or radiotherapy in the affected lower extremity. Indicators evaluated: history of exposure to solar radiation and radiotherapy, ${ }^{20}$ prior to the appearance of the wound.

- Chemical irritants: substances which alter the intake of nutrients or impair cell function, interfering in the health of the skin. Indicators evaluated: history of use of chemical products on the skin on the leg, causing irritation; history of skin contact with allergenic chemical products; history of smoking, alcoholism and use of contraceptives ${ }^{19-20,22}$ and other medications, such as chemotherapy agents. 
- Impaired circulation: conditions of venous and/or arterial circulatory alteration, as well as alteration in the lymphatic circulation in the leg(s). Indicators evaluated: history of alteration of the circulatory conditions of the lower extremities, existing at the time of the wounds' appearance; diagnostic examinations confirming vascular alterations; alteration of the peripheral perfusion, edema, reduced or absent peripheral pulse, pallor on elevation of the lower extremity, presence of lipodermatosclerosis, hemosiderosis, varicose veins, reticular veins and the Ankle-Brachial Index (ABI) below 0.9. ${ }^{19-20,22-23,25-26}$

- Fluid deficit: hydration conditions of the organism which are inadequate for maintaining homeostasis. In the context of vascular ulcers, this condition was considered coadjuvant, not being, in isolation, an event which directly causes impairment of integrity, with loss of the solution of continuity of the skin. Indicators evaluated: report of reduced fluid intake at the time of the appearance of the wound.

- Changes in the skin turgor: alterations in the skin texture. Increased or reduced turgor are coadjuvant factors. Indicators evaluated: history of edema and lipodermatosclerosis in lower extremities. ${ }^{19-20,22-23}$

- Nutritional factors: excess or deficit of substances which contribute to the health of the tissues and the healing process. Indicators evaluated: report of intake of foods in quantities or quality outside the standards recommended for adults, loss of appetite; Body Mass Index (BMI $)^{19-20,22-23}$ below $20 \mathrm{~kg} / \mathrm{m}^{2}$ or equal to or greater than $25 \mathrm{~kg} / \mathrm{m}^{2}$.

- Knowledge deficit: inadequate/insufficient knowledge regarding the prevention of the wounds and their complications. This is a coadjuvant factor, not being a direct cause. Indicators evaluated: relevance of the information which the individual stated that they had at the time prior to the appearance of the wound, and inadequate self-care practices related to the wound.

- Impaired physical mobility: reduction of the ability to move the legs, which impairs the person's ability to protect themselves from episodes of contact with pressure areas or reduction of the articulation of the ankle, capable of contributing to the reduction of the appropriate functioning of the calf muscle pump. Indicators evaluated: use of splints or other devices for physical immobilization of the affected limb and a history of reduction of capacity for plantar flexion and extension, prior to the appearance of the wound. ${ }^{20,23}$

The adding of the RF 'impaired metabolic state' $^{\prime}$ is proposed, defined as the alterations of the individual's metabolic conditions, with implications for the maintenance of tissue integrity. It is noteworthy that this RF is part of the list of factors considered as internal to the diagnosis of Impaired skin integrity, being an etiological element frequently observed in clinical practice, also, among persons with Impaired tissue integrity, as well as influencing the maintenance of the human response. For this, the following indicators were used: a history of diabetes mellitus, hypercholesterolemia, disorders relating to vasculitis with a rheumatological origin, or systemic hypertension. ${ }^{19-20,22}$ ${ }^{23} \mathrm{As}$ these two diagnoses overlap, it is plausible that the RFs for ISI may also be considered for ITI.

All the DCs were evaluated, through inspection by one of the researchers with a specialization in dermatological nursing, and were confirmed later, through analysis of the photographic records of the wounds by another researcher with experience in the teaching of semiotics in nursing. For the characteristics already present of the NANDA- $\mathrm{I}^{1}$ the following definitions and respective indicators considered in the clinical evaluation were elaborated, based on the understanding of the reversible and irreversible cellular injuries: ${ }^{26}$

- Injured tissue: tissue presenting a reversible cellular injury in which can be observed changes in the trophism, turgor, elasticity, micro-environment, and/or coloration, although without the loss of the solution of continuity. The cellular injury can occur due to: hypoxemia, alteration of the composition of the micro-environment, metabolic alterations, nutritional alterations, chronic inflammatory response, or exposure to chemical agents. The tissue wounds, in the context of vascular ulcers, are evidenced by the presence of lipodermatosclerosis, hemosiderosis, edema, erythema, hypotrichosis, cyanosis, and tissue pallor. The tissue wound can progress through to the destruction of the same.

- Destroyed tissue: tissue in which irreversible cellular injury has occurred, with exposure of the tissues (dermis, subcutaneous tissue, muscle fascia, muscle, tendon, bone), evidencing loss of the substance or absence of the tissue expected, according to the anatomy of the locale or presence of tissue necrosis (eschar and/or slough).

The DC of granulation and/or epithelialization tissue is proposed as an addition, as it evidences tissues characteristic of the proliferative and maturation phases of the healing process, which are frequently found in the wounds, not essentially meaning "destroyed tissue" or "injured tissue" ${ }^{20}$ These tissues evidenced the process of 
the synthesis of the new extracellular matrix. In this regard, they are tissues which are expected in the situation of resolution of the loss of the tissue integrity. The presence of these tissues may be perceived through direct inspection of the wound bed. It is reiterated that, for this study, there was no validation of this DC, representing purely a proposal based on the identification of this condition in the participants' wounds, and the researchers' clinical judgement, based in the specific literature.

Following the filling out of the data collection protocol by one of the researchers, which evaluated all the participants, the records were examined for analysis of the clinical indicators observed and judgement of the presence of each RF and DC, establishing the evidential support for the confirmation of the diagnosis studied. The records were examined by another researcher, independently, for validation both of the diagnostic confirmations and the presence of the RFs and DCs. For determining the degree of severity of the ulcer, one lesion was selected as principal, considering the parameters and the highest total score of the Pressure Ulcer Scale Healing (PUSH) tool used in another study. ${ }^{7}$ Its scale evaluates the healing conditions of the wound for the area in $\mathrm{cm}^{2}$, the quantity of exudate and the type of tissue in the wound bed.

The data were entered in a database in the Statistical Package for the Social Sciences for Windows ${ }^{\circledR}$, version 17.0. The analysis of the data was undertaken through procedures of descriptive statistics and, for the RFs, measurements of central tendency. The distribution of the number of RFs identified in each participant was studied, using the Kolmogorov-Smirnov test. For analysis of the difference of means of the RFs, the participants were grouped in relation to the history of recurrent principal wound evaluated (categorized as with and without history) how long the wound lasted (categorized as equal to or less than one year and greater than one year) and number of wounds (categorized as one and more than one wound), these being the clinical variables studied. For this, the Student $t$-test was used, and $\mathrm{p}<0.05$ was adopted.

The study is an excerpt of a larger project, approved by the Goiânia Municipal Health Department (GO) and by the Research Ethics Committee of the Federal University of Goiás (protocol N. 032/2008), All the participants signed the Terms of Free and Informed Consent.

\section{RESULTS}

Forty-two persons participated, with ages varying between 29 and 85 years old (mean of 60 years old \pm 12 years), $73.8 \%$ were male and $76.2 \%$ had not finished junior high school. They presented between one and four wounds, making a total of 63 wounds. All presented the nursing diagnosis of ITI. The following stand out as RFs: impaired circulation and knowledge deficit, with frequencies of $100 \%$, and chemical irritants, fluid excess and nutritional factors, occurring in more than half of the participants (Table 1).

In relation to impaired circulation, ascertained in all the participants, $90.5 \%$ presented exclusive characteristics of venous alteration, such as varicose veins, edema, ochre dermatitis, lipodermatosclerosis, white atrophy and $\mathrm{ABI} \geq 0.9$ with the absence of signs of impairment of the arterial circulation; $7.1 \%$ presented signs of alteration of both the venous and arterial circulation and $\mathrm{ABI}<0.9$. One participant $(2.4 \%)$ presented only characteristics of alteration of the arterial circulation (intermittent claudication, pallor on elevation of the lower extremities in less than 40 seconds, reduced pulse and $\mathrm{ABI}<0.9){ }^{19,22-23,25}$

Table 1 - Related factors identified in the participants with impaired tissue integrity, and defining characteristics, identified in the wounds. Dressings rooms in the primary care network of Goiânia (GO), February-August, 2009

\begin{tabular}{|l|c|c|c|c|c|}
\hline \multicolumn{1}{|c|}{ Related factors (n=42) } & $\mathbf{n}^{*}$ & $\mathbf{\%}$ & Defining characteristics (f=63) & $\mathbf{f}^{* *}$ & $\mathbf{\%}$ \\
\hline Impaired circulation & 42 & 100.0 & Granulation and/or epithelialization tissue & 63 & 100.0 \\
\hline Knowledge deficit & 42 & 100.0 & Destroyed tissue & 63 & 100.0 \\
\hline Chemical irritants & 40 & 95.2 & Injured tissue & 63 & 100.0 \\
\hline Fluid excess & 31 & 73.8 & & & \\
\hline Nutritional factors & 28 & 66.7 & & & \\
\hline Impaired physical mobility & 20 & 47.6 & & & \\
\hline Mechanical factors & 17 & 40.5 & & & \\
\hline Impaired metabolic state & 15 & 35.7 & & \\
\hline
\end{tabular}

${ }^{*} \mathrm{n}=$ participants; ${ }^{* *} \mathrm{f}=$ wounds 
In relation to the knowledge deficit presented by all the participants, it was identified that $40.5 \%$ of them were unaware of any of the factors involved in the development of vascular ulcers, $35.7 \%$ were able to cite only some of these factors and $23.8 \%$ mentioned exclusively trauma as being responsible for the development of the ulcer, being unaware of the role of their circulatory impairment in their wound's etiology.

Regarding the chemical irritants, identified in $95 \%$ of the participants, the researchers observed a history of smoking and regular consumption of alcoholic drinks; in the period prior to the development of the wound, $71.4 \%$ were smokers, and $19 \%$ were smokers who also drank alcohol regularly, in the study period. $64.3 \%$ of the participants also reported the regular use of medications which can have a negative influence on the integumentary health and/or circulatory function, such as oral contraceptives (female participants) and those used for female hormonal replacement.

Excess of fluid volume, expressed by edema in lower extremities prior to the development of the wound, was reported by $73.8 \%$ of the participants. Nutritional factors linked to below-normal weight, overweight or obesity, expressed by altered BMI at the time of the appearance of the lesion were inferred for $27.6 \%$ of the participants. Altered metabolic state was attributed to $35.7 \%$ of the participants, who reported diabetes mellitus (21.4\%) and dyslipidaemias (16.7\%).

Regarding impaired physical mobility, 47.6\% of the participants reported some alteration in mobility in the articulation of the ankle, prior to the wound which was in existence. Mechanical factors, represented by episodes of trauma on soft tissues, prior to the development of the wound, were reported by $40.5 \%$ of the participants, among whom $30.9 \%$ presented a concomitant report of large bone fractures in the lower limb affected.

The RFs of extremes of temperature, radiation and fluid volume deficit were not identified among the participants. Although $66.7 \%$ of them reported an increase in the temperature of the leg prior to the start of the wound, this finding was interpreted as evidence of the inflammatory state of local tissues, not being a factor of extremes of temperature capable of causing the loss of tissue integrity. In the same way, in spite of $33.3 \%$ of the participants mentioning frequent exposure of lower extremities to solar radiation, particularly resulting from rural work without protection of the same, the decision was made not to interpret this condition as evidence for the RF radiation, as this exposure was not sufficient to contribute directly to the appearance of the wound, and did not provoke burns. None of the participants presented a situation suggestive of fluid deficit prior to the appearance of the ulcer.

All the DCs were present, simultaneously, in $100 \%$ of the participants. All presented granulation tissue (in its varieties of texture and color), or islands of epithelialization tissue, in conjunction with slough or eschar, and subjacent and surrounding tissues presented signs of injury, resulting from the alterations of venous and/ or arterial circulation, including hemosiderosis, edema, or lipodermatosclerosis accompanied or not by evidence of arterial ischemia.

The number of related factors varied from three to eight (mean $5.577 \pm 1$ ) and there was a median of six. The distribution of the number of RFs identified in the participants had a normal distribution, according to the Kolmogorov-Smirnov test. No statistical difference was found of the mean number of RFs for those with and without a history of recurrence $(p=0.658)$, for those who had one or more wound in activity ( $p=0.157)$ and for those with a length of duration of the wound equal to or less than one year and greater than one year $(p=0.702)$.

\section{DISCUSSION}

The socio-economic and demographic characteristics are similar to the results obtained in other studies, ${ }^{2,26-27}$ except in relation to the predominant sex of the participants, as the most common situation of prevalence indicated in the literature ${ }^{2,8,19,26}$ is severe occurrence of vascular ulcers in women. However, the finding of the predominance of men in the population with vascular ulcers, attended in the dressings rooms in the setting studied, has been identified since 2007, in a study ${ }^{16}$ undertaken in large centers and where there is a greater demand for assistance, and later, in 2010, ${ }^{7}$ implying the need for specific studies for understanding this difference, in relation to the national and international scenario.

It was ascertained in a review of the literature that the nursing diagnosis of ITI, observed in all the participants in the present study, was not identified in other studies which investigated persons with vascular ulcers. ${ }^{15,18}$ In these studies, ISI was identified. This may have occurred due to the ulcers being superficial in the populations studied by these authors. 
The characteristics which evidenced the type of circulation impaired indicated the predominance of compromise of the venous circulation, which has higher prevalence among the vascular ulcers. ${ }^{6,16,19-20,22-23}$

Impaired venous circulation, as a RF of ITI, was unknown by the participants, as were the measures for improving venous return, preventing the occurrence of wounds. In this regard, the need for nursing interventions focussing on the development of a teaching/guidance plan for this population, with a focus on prevention both of loss of tissue integrity and of complications and worsening of the wound, may be seen. Among the preventive measures, healthy choices stand out, which include stopping smoking and drinking, which are harmful for the homeostatic mechanisms and nutritional balance and the health of the skin. ${ }^{19,22-23}$ Even though the frequency of smoking and drinking reduces during the wound process, the harm to the skin, resulting from these substances remains, even after use of the same has stopped. ${ }^{28}$

Although the NANDA-I taxonomy does not mention impaired metabolic status as a RF for ITI (although it does for ISI), this factor's influence on ITI is well established, which in its turn includes impaired skin integrity. Hence, its inclusion for the diagnosis studied is reasonable. Overweight or obesity stand out among the nutritional factors involved in the etiology of impaired tissue integrity related to impaired venous circulation. ${ }^{19,22-23}$ Increased body weight overloads the lower extremity vessels, requiring greater effort for venous return, which contributes to local venous hypertension. ${ }^{19,23}$ Diabetes mellitus and dyslipidemias reported by the participants also constitute conditions in which metabolic alterations occur, which influence skin integrity. These alterations can affect not only the more superficial tissues, but also those which are deeper, ${ }^{19-20}$ which characterize the nursing diagnosis studied.

Regarding impaired physical mobility, the lack of physical activity reduces the pumping action of the calf muscles, impairing venous return, already impaired by the chronic venous insufficiency. ${ }^{19-20,22-23}$ Trauma or fracture in lower extremities are important contributing factors in the triggering of the ulcer with a venous etiology, whether associated or not with thromboembolism. ${ }^{23}$ This event, in its turn, compromises the individual's mobility, thus creating a vicious circle. ${ }^{23-25}$

The macroscopic characteristics of the wounds, especially those relating to the type of tissue found in the wound bed of the venous ulcers were similar to those identified in other studies. ${ }^{7,26-27}$ In the NANDA-I taxonomy $\mathrm{II}^{1}{ }^{1}$ the DCs, which evidenced the diagnosis of ITI, do not mention the type of tissue found in the wound beds. In the process of wound healing, the stages overlap, it being common for the signs of the proliferative phase to occur concomitantly with the inflammatory phase. ${ }^{20,24}$ As a result, further studies are suggested for ascertaining the relevance of the including of granulation and/or epithelialization tissue as a DC of the diagnosis studied in this taxonomy.

The conditions studied (number of wounds, duration of the wounds, history of recurrence), which denote greater severity of circulatory impairment ${ }^{3,19,21}$ were not linked to the number of RFs. The implications of this situation of concomitance of related factors need to be studied more closely. However, one can foresee, a priori, one direct implication: the complexity of the therapeutic plan which these people require of nurses, in relation to the nursing diagnoses identified and the coverage of the interventions necessary for achieving the results expected, entailing responsibilities for the entire team of nursing professionals.

\section{CONCLUSION}

Studying the human responses includes the understanding of the unique aspects of the NDs in the different groups. In this study, the ITI, in persons with vascular ulcers, was related to eight of the 11 related factors stipulated in the taxonomy, with emphasis placed on impaired circulation, knowledge deficit, and the action of chemical irritants, fluid excess and nutritional factors, identified in more than half of the participants. This result denotes that the ITI in the groups studied requires a broad approach from nursing, not limited to the circulatory alteration, so as to ensure an individualized therapeutic plan with resolutive capacity. The lack of difference in the means of RFs presented by people with varying degrees of compromise of the circulation of the lower limbs may indicate that the concomitance of these RFs found in the population studied did not have direct implications in the severity of the tissue compromise; however, further research is suggested in this area.

As all of the participants had reconstruction tissue in the wounds, further studies are suggested for ascertaining the need for inclusion of the defining characteristic of granulation 
and/ or epithelialization tissue, in the NANDA-I taxonomy. In the same way, it could be useful to include altered metabolic state as a related factor for this diagnosis. The definitions for the RFs and DCs elaborated based in the literature for use in this study could be used and validated in other studies, so as to contribute to nursing clinical practice, and to the construction of the profession's scientific knowledge.

\section{ACKNOWLEDGEMENTS}

The authors express their thanks for the contributions of Dr. Flaviana Vieira, Dr. Isabelle Katherinne Fernandes Costa and Dr. Ruy deSouza Lino Júnior in the revision of the manuscript.

\section{REFERENCES}

1. Herdman TH, editor. NANDA-International Nursing Diagnosis: definitions and classifications 2012-2014.Oxford (UK): Wiley \& Blackwell; 2012.

2. Moffatt CJ, Franks PJ, Doherty DC, Martin R, Blewett $\mathrm{R}$, Ross F. Prevalence of leg ulceration in a London population. Q J Med. 2004 Jul; 97(7):431-37.

3. Fonseca C, Franco T, Ramos A, Silva C.A pessoa com úlcera de perna, intervenção estruturada dos cuidados de enfermagem: revisão sistemática da literatura. RevEscEnferm USP. 2012 Abr; 46(1):472-9.

4. Simms KW, Ennen K. Lower extremity ulcer management: best practice algorithm. J ClinNurs. 2010 Jan;20(1-2):86-93.

5. Silva MH, Jesus MCP, Merighi MAB, Oliveira DM, Santos SMR, Vicente EJD. Manejo clínico de úlceras venosas na atenção primária à saúde. Acta Paul Enferm. 2012; 25(3):329-33.

6. Edwards H, Courtney M, Finlayson K, Shuter $\mathrm{P}$, Lindsay E. A randomised controlled trial of a community nursing intervention: improved quality of life and healing for clients with chronic leg ulcers. J ClinNurs.2009; 18(11):1541-9.

7. Sant'anaSMSC, Bachion MM, Santos QR, Nunes CAB, Malaquias SG, Oliveira RGRB.Úlceras venosas: caracterização clínica e tratamento em usuários atendidos em rede ambulatorial.Rev Bras Enferm.2012 Jul-Ago; 65(4):637-44.

8. Silva FAA, Moreira TMM.Características sociodemográficas e clínicas de clientes com úlcera venosa de perna. Rev Enferm UERJ. 2011 Jul-Set; 19(3):468-72.

9. Oliveira BGRB, Nogueira GA, Carvalho MR, Abreu AM. Caracterização dos pacientes com úlcera venosa acompanhados no ambulatório de reparo de feridas. Rev Eletr Enferm [online]. 2012 [acesso 2013 Jan 10]; 14(1):156-63. Disponível em: http:/ / www.fen.ufg. br/fen_revista/v14/n1/pdf/v14n1a18.pdf
10. Maddox D. Effects of venous leg ulceration on patients' quality of life. Nurs Stand.2012 Mai; 26(38):42-9.

11. Salomé GM, Blanes L, Ferreira LM. Avaliação de sintomas depressivos em pessoas com úlcera venosa. Rev Bras Cir Plást. 2012; 27(1):124-9.

12. Costa IKF, Nóbrega WG, Costa IKF, Torres GV, Lira ALBC, Tourinho FSV, et al. Pessoas com úlceras venosas: estudo do modo psicossocial do modelo adaptativo de Roy. Rev Gaúcha Enferm. 2011 Set; 32(3):561-8 .

13. Moffatt CJ, Doherty DC, Smithdale R, Franks PJ. Clinical predictors of leg ulcer healing. Br J Dermatol. 2010 Jan;162(1):51-8.

14. Van Hecke A; Grypdonck M; Beele H; Vanderwee K; Defloor T. Adherence to leg ulcer lifestyle advice: qualitative and quantitative outcomes associated with a nurse-led intervention. J Clin Nurs. 2011Fev; 20(3-4):429-43.

15. Bersusa AAS, Lages JS. Integridade da pele prejudicada: identificando e diferenciando uma úlcera arterial e uma venosa. Ciênc Cuid Saúde. 2004 Jan-Abr; 3(1):81-92.

16. Martins MA, Tipple AFV, Reis C, Santiago SB, Bachion MM. Úlcera crônica de perna de pacientes em tratamento ambulatorial: análise microbiológica e de suscetibilidade antimicrobiana. Ciênc Cuid Saúde. 2010 Jul-Set; 9(3):464-70.

17. Oliveira PFT; Tatagiba BSF; Martins MA; Tipple AFV; Pereira LV. Avaliação da dor durante a troca de curativo de úlceras de perna. Texto Contexto Enferm. 2012 Out-Dez; 21(4):862-69.

18. Guedes HM, Nakatani AYK, Santana RF, Bachion MM. Identificação de diagnósticos de enfermagem do domínio segurança/proteção em idosos admitidos no sistema hospitalar. Rev Eletr Enferm [online]. 2009 [acesso 2013 Jan 10]; 11(2):249-56. Disponível em: http://www.fen.ufg.br/revista/ $\mathrm{v} 11 / \mathrm{n} 2 / \mathrm{v} 11 \mathrm{n} 2 \mathrm{a} 03 . \mathrm{htm}$

19. Conferencia nacional de consenso sobre úlceras de la extremidad inferior. Documento de consenso C.O.N.U.E.I [online]. Barcelona (ES): EdiKamed S.L; 2009 [acesso 2013 Jan 10]. Disponível em: http:// www.gneaupp.es/app/adm/documentos-guias/ archivos/8_pdf.pdf

20. Azulay RD, Azulay DR. Dermatologia. Rio de Janeiro (RJ): Guanabara Koogan; 2008.

21. Rutherford RB, Padberg FTJ, Comerota AJ, Kistner RL, Meissner MH, Moneta GL. Venous severity scoring: an adjunct to venous outcome assessment. J Vasc Surg. 2000 Jun; 31(6):1307-12.

22. Royal College of Nursing. The nursing management of patients with venous leg ulcers: recommendations [online]. London (UK): Royal College of Nursing; 2006 [acesso 2013 Jan 10]. Disponível em: http:/ / www.rcn.org.uk/__data/assets / pdf_ file/0004/107941/001269.pdf 
23. Doughty DB, Holbrook R. Lower-extremity ulcers of vascular etiology. In: Bryant RA, Nix DP. Acute \& chronic wounds: current management concepts. Philadelphia (ES): Mosby Elsevier; 2011.

24. Abbas AK, Fausto N, Kumar V. Robins\&Cotran. Patologia: bases patológicas das doenças. Rio de Janeiro (RJ): Elsevier; 2010.

25. Bergonse FN, Rivitti EA. Avaliação da circulação arterial pela medida do índice tornozelo/braço em doentes de úlcera venosa crônica. An Bras Dermatol. 2006;81(2):131-5.

26. Frade MAC, Cursi IB, Andrade FF, Soares SC, Ribeiro WS, Santos SV, et al. Úlcera de perna: um estudo de casos em Juiz de Fora - MG (Brasil) e região. An Bras Dermatol. 2005; 80(1):41-6.

27. Heinen MM, Persoon A, Kerkhof P, Otero M, Achterberg T. Ulcer-related problems and health care need in patients with venous leg ulceration: a descriptive, cross-sectional study. Int J Nurs Stud. 2006 Nov; 44(8):1296-303.

28. Avery MR, Voegeli D, Byrne CD, Simpson DM, Clough GF. Age and cigarette smoking are independently associated with the cutaneous vascular response to local warming. Microcirculation. 2009 Nov; 16(8):725-34. 